\title{
Can China's Green Socialism transform global capitalism?
}

\author{
O Socialismo Verde da China pode transformar o \\ capitalismo global?
}
¿Puede el Socialismo Verde de China transformar el capitalismo global?

(1) Jerry Harris ${ }^{1}$

\begin{abstract}
Over the past decade, China has made a spectacular leap to become the leading user and manufacturer of wind and solar power. However their commitment to fossil fuel still outweighs renewable energy. The article will trace the growth of clean energy and the coal and oil industry, in China's internal market as well as their global investments. It will examine both private and state-owned enterprises, show the transnational links embedded in global capitalism, and consider China's leadership in the transformation of the world's energy infrastructure.
\end{abstract}

Keywords: One Belt, One Road. Outbound investments. Solar power. Wind power.

Resumo: Na última década, a China deu um salto espetacular para se tornar o principal usuário e fabricante de energia eólica e solar. Mas seu compromisso com o combustível fóssil ainda supera a energia renovável. O artigo traçará o crescimento da energia limpa e da indústria de carvão e petróleo, no mercado interno da China, bem como em seus investimentos globais. Ele examinará as empresas privadas e estatais, mostrará os elos transnacionais embutidos no capitalismo global e considerará a liderança da China na transformação da infraestrutura energética mundial.

Palavras-chave: One Belt, One Road. Investimentos no exterior. Energia solar. Energia eólica.

Resumen: En la última década, China ha dado un salto espectacular para convertirse en el principal usuario y fabricante de energía eólica y solar. Pero su compromiso con los combustibles fósiles aún supera las energías renovables. El artículo rastreará el crecimiento de la energía limpia y la industria del carbón y el petróleo, en el mercado interno de China, así como sus inversiones globales. Examinará empresas tanto privadas como estatales, mostrará los enlaces transnacionales integrados en el capitalismo global y considerará el liderazgo de China en la transformación de la infraestructura energética mundial.

Palabras-clave: One Belt, One Road. Inversiones en el extranjero. Energía solar. Energía eólica.

\footnotetext{
${ }^{1}$ Global Studies Association of North America (Chicago, USA)

author_biographical_data
}

Civitas, Porto Alegre, v. 19, n. 2, p. 354-373, May-Aug. 2019

Este artigo está licenciado sob forma de uma licença Creative Commons Atribuição 4.0 Internacional, que permite uso irrestrito, distribuição e reprodução em qualquer meio, desde que a publicação original seja corretamente citada. https://creativecommons.org/licenses/by/4.0/deed.pt_BR 


\section{Introduction}

China's solar and wind industries have surged to global leadership within the last decade. Rapid advances were achieved once the Chinese Communist Party (CCP) came to understand the strategic dangers of global warming, fossil fuel pollution, and the developmental opportunities such problems presented. Although most solar and wind companies are private, in 2006 the government took an active hand when state-owned banks began to provide $\$ 18$ billion in low-interest loans. Cheap loans, cheap land offered by regional governments, and cheap labor, all helped propel Chinese companies to transnational prominence. Moreover, a number of large state-owned enterprises (SOEs) also entered the field. As noted by Michael Liebreich, Chairman of the Bloomberg New Energy Finance advisory board, "China has already shown signs of willingness to step into any leadership vacuum left by the U.S., and it has the financial and technological firepower to do so effectively" (Liebreich and McCrone, 2017).

Solar and wind power occupy an important part of the "Made in China 2025 " strategy by which China hopes to be an industrial leader in high tech areas, including aircraft, high-speed trains, computer chips, robots, and EV cars. China's unique system of state planning and market socialism has translated into a strong position in the race to lead the global alternative energy revolution. This not only includes cheap state loans, but also extensive research subsidies, and a push to outbound capital for mergers and acquisitions. China's statist transnational capitalist class (TCC) works in close coordination with the private sector in promoting renewable energy. This works well for the internal development of the industry, but importantly also for the push into global markets in which both state and private TCC fractions work closely with TCC sectors in other countries in what President Xi calls a "win-win" strategy. The International Energy Agency predicts that over the next five years 1,000 new gigawatts $(\mathrm{GW})$ of renewables will be installed globally, a target that coal took 80 years to achieve. An explosive economic field in which China plans to be the major player, not only for its own companies but for global capitalism.

\section{China's renewable energy industry}

China invested $\$ 132$ billion in clean energy in 2017, over a third of the world's total and by far the most of any country. Chinese investments are expected to run about $\$ 71$ billion a year through 2020, and Bloomberg predicts China will add 21 solar GWs per year out of global growth of $75 \mathrm{GWs}$ (Liebreich and McCrone, 2017). Overall, China will invest $\$ 360$ billion 
in renewables over the next five years, with the possibility of creating 13 million new jobs. The renewable sector already employs a million more workers than China's oil and gas industry. China has five of the top ten wind turbine companies, and five of the world's top ten solar manufactures. The majority of Chinese wind and solar investments are going to the US, Germany, Italy, Australia, and South Africa, but Latin America has also attracted significant attention.

Figure 1 - World wind energy market update, 2016

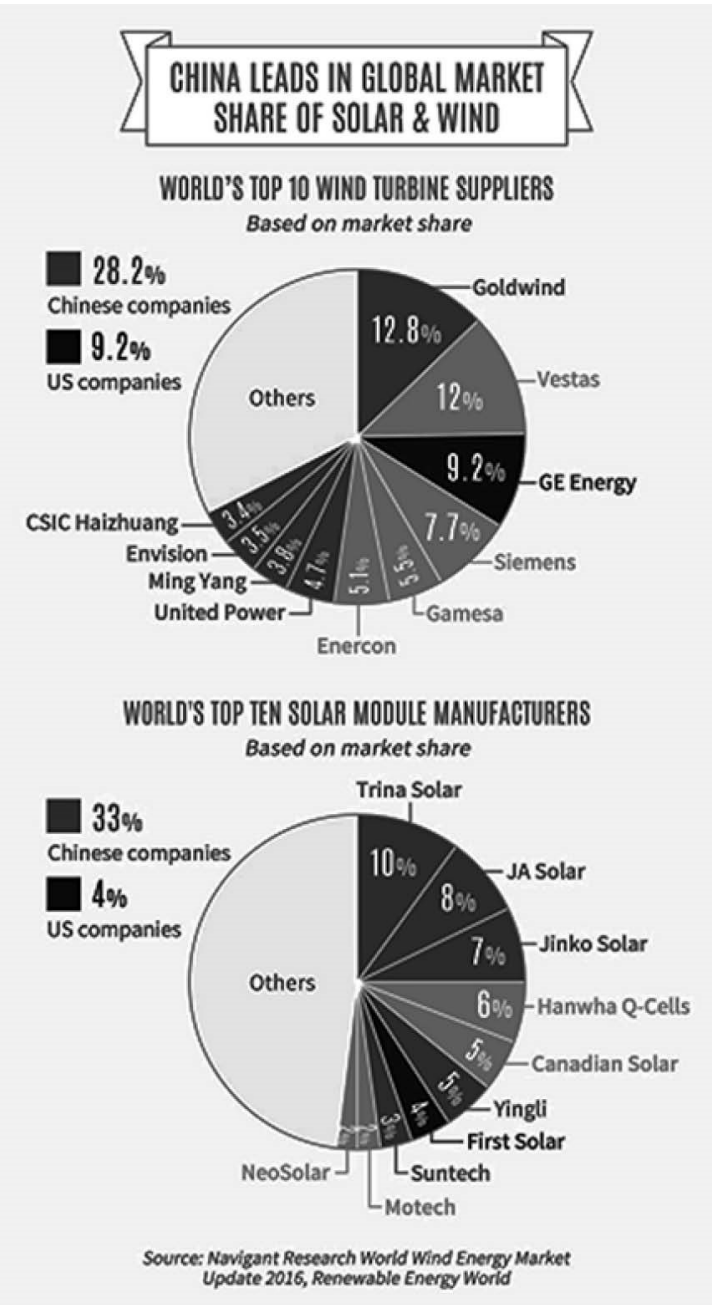


When it comes to solar power China has become the largest global manufacturer and installer of solar panels with two-thirds of the world's production. Counting Chinese owned factories throughout Asia, their share of global sales reaches 80 percent (Bradsher, 2017c). In 2017 China invested $\$ 86.5$ billion in solar power out of the world's total of $\$ 160.8$ billion (BNEF, 2017b). China also held more than half the world's solar jobs, employing 3.1 million workers. This compares to 260,000 in the US solar industry (Irena, 2017). By 2021 China is expected to have 40 percent of the world's solar capacity. In terms of exports, at the beginning of 2017, 56 percent of China's global solar sales went to the global South totaling $\$ 4.446$ billion. Japan and India were the number one and two buyers of China's PV exports (BNEF, 2017a). The solar industry has gone through a cycle of overproduction, bankruptcy, centralization, and monopolization. Some of the biggest solar companies, including Suntech, Chaori, and LDK Solar, defaulted on state loans. China now has about 80 solar companies, down from 800 just a decade ago.

Workers employed in China's wind industry reached 509,000, about half of the global total and much larger than the 102,500 employed in the US. The US is highly concentrated with GE (US), Vestas (Denmark), and Siemens (German) accounting for 86 percent of production capacity and 94 percent of the market. In China, domestic production supplies 97 percent of the local market (IRENA, 2017). China's wind capacity is growing so rapidly on average it installs two wind turbines an hour. By 2015 it had 34 percent of the world's total capacity. Nevertheless, important problems remain, particularly the lack of transmission lines to carry electricity to the coastal urban centers. Even with this tremendous growth, wind and solar power only account for 15 percent of China's overall energy use.

To obtain a picture of China's alternative energy industry we will look at three of the largest privately owned companies and three SOEs. What we see throughout the industry is that China's push to go global has created transnational corporations (TNCs) in both the private and state sector. These TNCs have received significant state support politically and economically, and are part of China's strategy of becoming a leader in renewable energy sources. They are also linked to other transnational actors through investments, joint projects, mergers and acquisitions. We begin with the two largest privately owned solar TNCs, JinkoSolar, and Trina, which have vied back and forth in competition to be the world's largest manufacturer of solar panels.

JinkoSolar has established a vertically integrated solar product value chain. It has 15,000 employees, with eight manufacturing sites located in 
China, Malaysia, Thailand, South Africa, and Portugal. Moreover, it has 16 overseas subsidiaries in Japan (2), Singapore, India, Turkey, Germany, Italy, Switzerland, United States, Canada, Mexico, Brazil, Chile, Australia, South Africa, and United Arab Emirates (JinkoSolar, 2018). It not only has the number one market share in China, but also in Brazil, Chile, Mexico, Italy, and South Africa. It partnered with Marubeni from Japan in the world's largest solar project for 2017, a $1.2 \mathrm{GW}$ plant in the United Arab Emirates, and also took 20 percent in the world's largest solar farm, the Sweihan power plant in Abu Dhabi. Because it can ship panels from facilities outside of China it can avoid the tariff penalties imposed by the Trump administration.

Trina Solar has 14,000 employees with manufacturing plants in China, Malaysia, Thailand, and the Netherlands. It has regional headquarters in California, Zurich, Singapore, and Tokyo. Trina maintains research and development facilities in Australia and holds 1,300 patients. About 26 percent of its sales are in the US, 18 percent in Europe, and 13 percent in China. It was named the "most bankable" in the solar industry by Bloomberg New Energy Finance (Buckley et al., 2017). Chairman and CEO Jifan Gao is an excellent reflection of the Chinese TCC, networked into several important organizations. He is president of the China Photovoltaic Industry Association, co-chair of the Global Solar Council, vice president of China Chamber of Commerce, and founding member of the Private Sector Advisory Board for the United Nations Development Programme. Other top Trina executives have similar transnational connections. Stephanie Shao, Chief Human Resources Officer, previously worked for Fortune 500 companies Colgate Palmolive, Bristol-Myers Squibb, and Dun Bradstreet. Chief Branding Officer Colin Yang served for 20 years in China's diplomatic core and worked for Cisco and Siemens. David You, head of International System Business Unit, worked for SAES Group of America and MW Zander of Germany (Trinasolar, 2018). Such connections attest to the organic development of the TCC rooted in transnational business experiences that enhance personal global connections and help develop a shared class consciousness.

Goldwind is the largest wind turbine producer in the world, with 25 percent of the Chinese market, over twice as much as its nearest competitor. It has installed 19,000 turbines in 17 countries on six continents, including wind farms in the US, Australia, Panama, Romania, Pakistan, Thailand, Ecuador, Chile, and South Africa. Under the One Belt, One Road (Obor) initiative it is building one-third of Pakistan's wind capacity. In the US Goldwind has acquired two Texas wind farms and supplies turbines in Wyoming. Goldwind's US subsidiary is headquartered in Chicago with financing from Berkshire 
Hathaway Energy and Citi. It has also raised capital through a \$300 million green bond. Furthermore, Goldwind and Apple have entered a joint agreement for Chinese windfarms in which Apple holds 35 percent (Buckley et al., 2017). Its $R \& D$ work is carried out in Denmark, Germany, Australia, the US, and China.

The largest clean energy group is China Three Gorges Corporation (CTGC). While the majority of its energy is generated by dams, an industry criticized for displacement and environmental disruption, the company also invests in solar and wind power. CTGC has a 21-percent stake in Energias de Portugal (EDP), acquired when the Portuguese government privatized its ownership stake. CTGC is now the largest shareholder in the utility, and also holds a minority stake in EDPs wind farms. To consolidate their relationship the two TNCs set up a joint venture to invest in hydro-electrical power in Africa and South America. They are particularly active in Brazil, where CTGC also took a 49-percent stake in EDP's Brazilian wind portfolio. China Three Gorges South Asia Investment Limited was established in Pakistan focused on becoming the country's largest alternative energy company. It holds solar, wind, and hydropower projects, and the World Bank has a 15-percent equity stake. CTGC is also active in India, Malaysia, and has five hydropower projects in Africa. In Europe, CTGC holds a 30-percent stake in an offshore wind farm in Scotland, and from Blackstone acquired the German company WindMW $\mathrm{GmbH}$, which has one of the largest offshore wind farms in the North Sea. To help its global expansion CTGC launched China's largest green bond sale for $\$ 900$ million (Buckley et al., 2017).

The State Power Investment Corporation (SPIC) is one of the largest state-owned electricity generators in China, 35 percent of which comes from clean energy. Its major footprint is in offshore wind power, in which it is China's leading developer. SPIC is active in 36 countries with $\$ 113$ billion in foreign assets. It holds 19 hydro and wind energy projects in Australia, Chile, and Brazil. Its solar investments include Japan, Turkey, Malta Tanzania, Mozambique, and Argentina. In Pakistan, it bought a 66-percent stake in K-Electric from the private equity firm Abraaj Group of Dubai, promising a $\$ 9$ billion investment in the electricity infrastructure of Karachi. This acquisition fits well into the Obor strategy and the $\$ 46$ billion China-Pakistan economic corridors (Buckley et al., 2017).

China General Nuclear Power Group (CGN) began to diversify into clean energy in 2007. It now operates $10 \mathrm{GW}$ of wind power and $4.1 \mathrm{GW}$ of solar and hydro energy compared to $17.1 \mathrm{GW}$ of nuclear power. Its total of $14 \mathrm{GWs}$ of clean energy makes it one of the world's largest renewable 
energy TNCs. In the UK it has an 80-percent stake in the Clover wind farms, but its main European relationship is with France. It has a large joint venture with the French solar company Inovia Concept Development. With the French firm Eolfi, ICD won a bid to build an offshore floating wind farm working in cooperation with the French navy and energy group DCNS. Also from Eolfi, CGN bought the onshore Fujin wind farm in France. Furthermore, it joined EDF of France to build the Hinkley Point nuclear power plant in the UK, and developed a wind project in Namibia that also includes the French solar farm developer InnoSun. To cement its strong relationship and focus on solar and wind investments it set up CGN European Energy headquartered in France. CGN also acquired a 90-percent stake in a solar farm project in Senegal from Italy's Chemtech Solar. And from Gaelectri in Ireland, it bought 14 wind farms and acquired full ownership of the largest onshore wind farm in Belgium $(\mathrm{Ng}$, 2016).

Other notable examples of the transnational character of China's renewable energy industry includes JA Solar, which generates 57 percent of its revenues outside of China. In Hungary, it works with Manitu, Essel Infraprojects in India, Soventix in Chile, and Powerway in South Africa. As with other Chinese solar TNC's it operates a manufacturing plant in Malaysia. GCL-Poly Energy Holdings, the world's largest solar wafer producer, raised \$253 million in green bonds to build eight solar farms. GCL has highly automated plants, doubling its production while laying-off about half of its workforce. China Longyuan Power Group partnered with Czech engineering firm SWH Group to invest $\$ 600$ million in green energy in central and Eastern Europe. Shunfeng International Clean Energy's bought out Germany's S.A.G. Solarstrom and the US firm Sunvia (Gupta, 2017). China Sunergy partnered with Dubai-based Energon Technologies to build a solar plant in Bangladesh. Also building solar plants in Bangladesh is a consortium consisting of Zhejiang DunAn New Energy, China National Machinery, Solar Tech Power (US), and Amity Solar (India) (Buckley et al., 2017). In Argentina, of 12 new wind projects Chinese companies have secured half, and 75 percent of solar energy bids have been won by Chinese TNCs. China also has the most solar energy installed capacity in Brazil, Chile, Mexico, and Uruguay (Koop, 2017).

All this activity points to the integrative transnational strategy typical of global capitalism. Chinese "national champions" maintain a wide array of relationships, joint projects, joint investments, and joint financing. Reflecting on China's growing transnational investments, Tim Buckley from the Institute for Energy Economics and Financial Analysis stated, "As the US owned the advent of the oil age, so China is shaping-up to be unrivalled in clean 
power leadership today. The US may look back in regret in years to come" (Middlehurst, 2017).

Cross border green investing has become an ingrained part of transnational capitalism. As part of these global capital flows green bonds have become popular financing tools, and the Chinese state and private companies are the most active players. The Peoples Bank of China (PBC) estimates annual investments running from $\$ 320$ billion to a high of $\$ 640$ billion to meet the carbon levels agreed to in Copenhagen. The PBC sees the market playing the main role, claiming that 85 percent of the funds will need to come from the private sector (GSIA, 2016). An important step was taken when the Bank of China offered a $\$ 500$ million green bond on the London Stock Exchange, connecting to a key pool of transnational investors. Underscoring the importance of the green economic strategy, the PBC issued "Guidelines for Establishing the Green Financial System," co-signed by the Ministry of Finance, the Ministry of Environment Protect, the China Banking Regulatory Commission, and the China Securities Regulatory Commission (Aitken, 2016). Moody's credit rating agency registered $\$ 93.4$ billion in green bonds in 2016, with China far in the lead with 40 percent of the world's total (Xinhua, 2017).

When it comes to China's solar and wind companies, domestic and world stock markets play a vital role in providing capital. Some 31 Chinese solar and wind companies are listed internationally and are present on all the largest stock markets. This allows these TNCs to raise money and play an active role in the OBOR expansion. Additionally, they have access to the $\$ 4.8$ billion Green Ecological Silk Road Investment Fund run by the Chinese Development Bank (CDB). China's foreign investments in renewable energy hit $\$ 32$ billion alone in 2016, and this included 11 deals worth more than $\$ 1$ billion each (Tianjie, 2017). As Daniel Mallo, head of Asia Pacific Energy at Societe Generale, noted, "If you are a mergers and acquisitions banker seeking to sell renewable energy assets, Chinese buyers will certainly be top of your potential target list" $(\mathrm{Ng}, 2016)$.

China's renewable energy efforts have been spectacular in the context of the overall efforts of global capitalism to mediate global warming. But China's commitment to developing sustainable energy conflicts with other economic imperatives. Although China serves as an example of state planning and directing markets, it still competes within the rules of capitalism, which structures its choices and limitations. And just as the competitive conflict between green energy interests and the fossil fuel industry exists in the US, the same contradictions are evident in China. As Qin Haiyan, head of the Chinese 
Wind Energy Association, stated: "The conflict between coal and wind will become even fiercer in the next few years" (Wong, 2015).

\section{Fossil fuel roadblocks}

Even though the CCP has halted plans for 103 new coal plants, coal is still the largest source of energy with China burning more coal than the rest of the world combined. Coal companies and utility grid corporations carry a lot of political weight, particularly when shut-downs cause unemployment and social disruption. This is especially true in the coal-rich northern providences where the China Kingho Energy Group, the country's largest private mining concern, holds influence over local governments. There are four million coal miners in China generating 70 percent of the country's electricity (Bradsher, 2017b). And the State Grid Corporation, one of China's largest and richest state-owned enterprises is also one of the largest owners of coal power plants. Greenpeace reports that the big state-owned electricity generators are still adding new coal-fired plants at a rapid rate, bringing on-line about one gigawatt of capacity per week (Forsythe, 2016). And in 2016 three new wasteful and polluting coal-to-gas plants were approved by the Ministry of Environmental Protection. Utility operators have also been slow to add a larger percent of clean energy to the grid, causing the government to direct them to compensate solar and wind producers. As in many countries, the struggle between fossil fuel interests and clean energy plays out against the backdrop of governmental policy. The central state hopes to limit coal consumption to 58 percent of total energy use by 2020 .

Coal is also playing an important role in China's Obor strategy. Obor is perhaps the most expansive and important transnational project in the world, promising over a trillion dollars of infrastructure investments spanning from europe, through africa, the middle east, and on to asia. As Joe Kaeser, the chief executive of Siemens noted: "The China One Belt, One Road is going to be the new W.T.O." (Bradsher, 2018). Although China has pledged sustainable development, OBOR contracts are helping coal companies adjust to closures at home, and SOEs are involved in over two-thirds of the coal projects. Overall, Chinese corporations are committed to 700 new coal plants, 20 percent to be built abroad. Since 2001 China participated in 240 coal power projects in 25 countries, their involvement growing 300 percent since Obor was proposed in 2013 (Ren et al., 2017). Countries include India, Bangladesh, Indonesia, Sri Lanka, Vietnam, Egypt, Pakistan, Iran, Russia, Kazakhstan, Bosnia \& Herzegovina, Australia, the US, and Malawi. Eleven of the world's 20 largest coal developers are from China (Tabuchi, 2017). With the World Bank and 
Asian Development Bank sharply cutting back their financing of coal, the China Development Bank and Export-Import Bank of China has stepped in. The estimated yearly cost to the climate, local health, and pollution of China's overseas coal investments is $\$ 29.7$ billion (Gallagher, 2016). Climate Policy Initiative researchers estimate $\$ 35$ to $\$ 72$ billion in new overseas coal plant investments in the near future. If all the coal plants financed by Chinese policy banks were added together they would be the eighth largest emitter of carbon dioxide in the world.

Table 1 shows energy investments by China's two major development banks, the CDB, and the Export-Import Bank. These banks show a clear picture of state policy decisions on where to focus their capital.

Table 1. Distribution of overseas investments by Chinese development banks, 2000-2016

\begin{tabular}{lc}
\hline Energy Type & $\begin{array}{c}\text { Amount } \\
\text { (\$ billions) }\end{array}$ \\
\hline Oil & 54.6 \\
Coal & 43.5 \\
Hydro & 24.9 \\
Gas & 18.8 \\
Nuclear & 9.9 \\
Solar & 2.4 \\
Wind & 1.7 \\
Total & $\mathbf{1 5 9 . 8}$ \\
\hline
\end{tabular}

Source: Gegi, 2016.

The top five countries receiving investments are Russia $\$ 41.5$ billion, Brazil \$20.4 billion, Pakistan $\$ 18.7$ billion, India $\$ 7.3$ billion, and Vietnam at $\$ 6.4$ billion. The next three are all in Latin America with Venezuela at $\$ 5$ billion, Argentina $\$ 4.9$ billion, and Ecuador $\$ 4.8$ billion. Latin America, Europe, and central Asia are all recipients of large oil investments, in Asia coal is the number one, and Africa attracts more hydropower investments (Gegi, 2016).

China's main global focus remains oil and gas. All three oil majors, The China National Petroleum Corporation (CNPC), China National Petrochemical Corporation (Sinopec), and China National Offshore Corporation (CNOCC) are closely aligned with the state's energy and financial bureaucracies. The 
Ministry of Land and Resources, the State-Owned Assets Administration and Supervision Commission, the Ministry of Commerce, and the National Development and Reform Commission all promote the global expansion of the oil majors to secure resources and technology, promote trade, and grow stateheld assets. On the financial side the Ministry of Finance, the People's Bank of China, Export-Import Bank of China, and the China Banking Regulatory Commission all play important roles in mobilizing capital for global energy investments, cross border mergers and acquisitions, and overseas stock holdings. These financial intuitions are closely linked to the four largest Chinese banks and sovereign wealth fund. For example, the Ministry of Finance is the largest shareholder of the Bank of Communications, the CDB, and has three special funds that include the global expansion of fossil fuel projects. It oversees the China Investment Corporation, which is the country's largest sovereign wealth fund, which in turn acquired Central Huijin, the largest shareholder in China's four largest commercial banks. The People's Bank of China oversees foreign reserves, the Silk Road Fund, and holds nearly \$2 billion of energy assets on the London Stock Exchange (Bo et al., 2016). China's oil majors have privileged ties to all these institutions, and could not exist without access to their deep pools of capital.

These overlapping relationships reveal how closely the statist transnational class is tied to the oil and gas industry and its global network of production and investments. But the above relationships are not simply Chinese, they are embedded in capital relations between different global sectors of the TCC. BlackRock, the world's largest financial institution, has holdings in China's biggest banks and oil majors, as do many other financial groups such as Fidelity, HSBC, and JP Morgan. Even the CDB, an arm of state policy, has 27 percent of its stock owned by the US investment firm Buttonwood (Xu et al., 2017). Between 2000 and 2014 CDB made energy loans of about $\$ 86$ billion to governments throughout the world and provided CNPC with $\$ 30$ billion in low-interest loans for overseas expansion (Xu et al., 2017). After the 2008 crash, CDB became the world's largest financial institution issuing overseas loans.

Another role for transnational financing of oil and gas SOEs is through China's corporate bond market, now the third largest in the world after the US and Japan. CNPC, Sinopec, and CNOCC issued dollar bonds worth \$26.6 billion over 2012-2013, and the State Grid Corporation raised \$11 billion over 2013-2014. CDB has also turned to the foreign bond market raising about $\$ 4.4$ billion. Although still limited, these are growing and strategically important avenues to foreign capital investments. Additionally, because of 
the weakness of China's domestic stock markets, TNCs turn to global stock markets to help finance their international expansion. For example, in 2013 over 34 percent of the capital for cross-border M\&As came from overseas financing. And between 2013 and 2015 Chinese companies raised more from foreign stock markets than their domestic counterparts did. As Bo et al. (2016, p. 17) point out, equity financing of China's three oil majors on the world's stock markets "constituted a milestone in their global expansion." Foreign banks are also in the mix, making loans for China's oil TNCs for cross-border acquisitions. All this indicates how close are TCC economic ties, and how China's outbound focus and Obor strategy further globalization for many different economic interests.

When China's TNCs expand abroad mergers and acquisitions (M\&As) attract far more capital than new greenfield investments. Nevertheless, both investment types are concentrated in fossil fuels at better than 90 percent. Most M\&As take place in industrialized countries, while most greenfield projects are in the global South.

Table 2. Sectoral distribution of Chinese global M\&As in energy, 2000-2015

\begin{tabular}{lcccc}
\hline Sector & $\begin{array}{c}\text { Deal value } \\
\text { (\$ millions) }\end{array}$ & $\begin{array}{c}\text { Percentage of } \\
\text { deal value } \\
\text { total }\end{array}$ & Deal number & $\begin{array}{c}\text { Percentage of } \\
\text { deal number } \\
\text { total }\end{array}$ \\
Electric Power & $31,538.44$ & 14.86 & 95 & 22.25 \\
Oil \& Gas & $170,675.40$ & 80.42 & 309 & 72.37 \\
Solar \& Wind & $10,013.17$ & 4.72 & 20 & 4.68 \\
Hydro & 0.60 & 0.00 & 2 & 0.47 \\
Total & $\mathbf{2 1 2 , 2 2 7 . 6 1}$ & & $\mathbf{4 2 7}$ & \\
\hline
\end{tabular}

Source: The globalization of Chinese energy companies: the role of state finance, Gegi, 2016.

As we see from all the above data, China is still deeply committed to fossil fuels, not only for its internal market but also its global expansion. Although renewable energy will play a growing role in the years ahead, coal, oil and gas investments far outstrip clean fuel sources. The inevitable contribution to global warming and pollution is unavoidable. China's push to transform global energy use is admirable, but still too little to transform the commitment of global capitalism to its fossil fuel infrastructure and market. 


\section{Structural economic roadblocks}

China's continuing expansion of fossil fuels is evidence of deeper structural problems lodged in the system's expansionary and recessionary cycles. The need for ever greater amounts of accumulation inevitably pushes capitalism towards continual growth. This is the fundamental logic behind the Obor strategy, which encompasses some 64 countries. China's overaccumulation of capital, and its saturated internal markets for commodities such as steel and concrete, results in a drive to find foreign markets for investments and sales. Although committed to seeking environmentally sustainable projects, Obor's promotion of ports, highways, dams, railroads, airports, trade, and production means greater carbon emissions, more pollution in the oceans and atmosphere, cutting down forests, the use of more natural resources, and burning more fossil fuels. Even with building solar and wind projects, the environmental impact will be immense.

Capitalism may have the ability to disconnect accumulation from growth, at least theoretically. Sustainable technologies are in existence in the fields of energy, transportation, architecture, agriculture, pollution control, and production itself. The corporations that develop and deploy these technologies can profit by shrinking the environmental footprint of capitalism, and become the industrial giants of the future. Essentially expanding their accumulation of capital by limiting environmentally destructive growth. Such an economic evolution would be a fundamental reordering of capitalism, creating a sustainable society yet still committed to market relations. The roadblock does not lie with technology, but capitalist social relations that prevent their speedy development and full application.

This was evident in the bankruptcy of dozens of solar companies in the last recessionary cycle that hit in 2008. China's state promotion and subsidies to solar panel manufacturing resulted in rapidly expanded production and a significant 70-percent reduction in price, just the type of advance in environmental technology needed to make important inroads against global warming. But transnational corporations and finance only saw a competitive danger. Lower prices meant lower profits. And the global capitalist market could not react quickly enough to absorb Chinese production. Worldwide the demand was for $30 \mathrm{GWs}$ of solar power, but enough panels were produced for a capacity of $70 \mathrm{GWs}$. The result was a steep drop in stock prices, lay-offs, bankruptcy, and closed factories.

Both the US and Chinese industries were hard hit. Top US producers saw a plunge in stock prices. Suntech suffered a loss of 61.7 percent, First 
Solar sank 55.8 percent, and MEMC dropped 57.8 percent. Commenting on conditions in China, Li Junfeng, president of the Chinese Renewable Energy Industries Association, said the following:

[...] solar panel industry was like 'a patient on life support' that would have to undergo radical consolidation and cuts to emerge from the crisis of overcapacity [...] there is no way to solve this crisis (without) powerful market competition and cruel elimination (Clark, 2013).

Bankruptcy and eliminations did occur, and yet another crisis hit in 2016. This time Chinese solar panel prices were cut 25 percent in a competitive struggle for markets, brought on by overproduction. As The New York Times reported, "Western companies found themselves unable to compete, and cut jobs from Germany to Michigan to Texas and points beyond" (Bradsher, 2017a). The world's capacity of 139 GWs still sits far above the market's current consumption of about 77 GWs per year. Consequently, China's rapid expansion of solar power, which brought down prices close to 90 percent has undercut the global industry once again. Patrick Pouyanné, the chairman and chief executive of the French oil giant Total, commented: "The solar industry is facing again, I would say a new winter" (Bradsher, 2017a).

The McKinsey think tank has argued forcefully that market-supplied solar energy needs to be profitable. As their study notes, "As more companies enter the market for solar projects, competition intensifies - and profits narrow." The result in 2015 and 2016 was a "significant value erosion," and therefore companies will need to "aggressively manage costs," get "bigger," and "figure out how to generate not just clean energy but also good financial returns," because "institutional investors want a healthy yield at low risk" (Frankel et al., 2016). Here are all the pressures of the market. The competitive drive towards monopoly to ensure profits, aggressively lowering costs, which means lower wages, and the primacy of investor's needs over supplying clean energy. The well-being of both workers and the planet are secondary to the desire for expanded accumulation. In other words, social relations are the chains holding back the development of the productive forces, i.e. renewable energy.

This is why Kevin Gallagher of Boston University and Jiajun Xu of The Center for New Structural Economics state that, "Development Banks arguably have the most important role in triggering a low-carbon transformation of the world economy" because the private market place is not equipped to supply the one trillion dollars needed in yearly investments (Jiajun et al., 2017). 
Particularly in an industry with high risk and high capital intensity. The transition to green energy needs long-term capital investments, which private financial institutions focused on short-term returns cannot supply. Neither can governments committed to neoliberal austerity fully supply the capital needed. The hope of Gallagher and Jiajun (2017) are that the 250 development banks situated in the global South with $\$ 5$ trillion in assets can lead the way because, "Rather than pursuing profit maximization as commercial banks do, development banks are geared towards achieving public policy objectives." For the authors a state-directed, green industrial policy is the best way forward, indicating a socialist direction of development outside the straight-jacket logic of narrow market imperatives.

The market has also failed to develop robust carbon pricing, although countries still push carbon credits as a major device to control fossil fuel emissions. China is experimenting with carbon credits sales, moving to create the world's largest market covering 3.3 billion tons of yearly releases. The market works with the government setting limits on the amount of pollution allowed, dividing that into emission permits given or sold to corporations. Participating enterprises can use permits to discharge their allowed amount of carbon, or cut pollution and sell leftover permits to those factories that have gone over their pollution limits. But such a market has largely failed in the EU. Bloomberg reported that carbon trading has "already proven that they are too volatile to drive investment decisions (and) now it seems even speculators have given up on them...truly there is a need for a complete rethink" (Liebreich, 2016). Blocking a "complete rethink" is the inability of the TCC to operate outside of competitive markets and market incentives to solve social and environmental problems. Yet the climate crisis calls for a planetary political response and worldwide planning that goes beyond anything suggested from agreements in Paris, Copenhagen, Kyoto, or shallow carbon market manipulations.

In Copenhagen, wealthy OECD countries promised $\$ 100$ billion per year for clean energy development in the global South. But in the seven years between 2010 through 2016 cross-border investments (including those from developing countries) only totaled $\$ 112$ billion. About $\$ 600$ billion short. The supremacy of fossil fuel can be seen in figures from 2014 when cross border fossil fuel investments were $\$ 60.5$ billion and OECD clean energy investments in developing countries just $\$ 10.3$ billion (Climatescope, 2017). As the Renewable Energy Policy Network for the 21st Century reports, fossil fuel, and nuclear power subsidies continue to "dramatically exceed those for renewable technologies" (Rueter et al., 2017). 
The first response of the capitalist market is always to profits, not human or planetary needs. The relationship between the TCC and the rest of humanity takes place primarily through the market. This arises from the fundamental contradiction in social relations between capital and labor. If capitalism cannot make money from the green business it will not invest in that industry. Consequently, recessionary cycles will impact the ability of capitalism to transform itself into a sustainable society, just as its growth cycle creates greater environmental impact by seeking expanded accumulation. The development and application of green technologies will always be subject to the internal driving logic of capitalism embedded in its social relations. Private profits must come from social labor. And labor, even if producing a social good will not be supported if not profitable.

\section{Conclusion}

China's promotion of clean energy has used both, the state and the market in what the CCP describes as market socialism. Compared to the US and other industrialized countries China's record is outstanding, showing how a sophisticated use of state planning and the market can rapidly develop renewable energy. And yet China's wide-ranging outbound investments in fossil fuels have a global impact. Consequently, it is not just that China has become the world's largest emitter of domestic fossil fuels (much of it displaced Western manufacturing), but that fossil fuels continue to occupy the key position in both its foreign and internal markets.

Can China expand and export its green market socialism into global capitalism, pushing the world system towards accumulation without environmentally destructive growth? The CCP maintains Obor is a "winwin" strategy, a new type of developmental foreign policy free of imperialist overtones. But can economic development based in global capitalist markets produce socialist relations and culture? China's policies may promote a more multi-centric world order, one in which states in the global South have more say. But where is labor in this "win-win" scenario? Socialism seeks to revolutionize the relations of production between capital and labor, making social labor and use value primary. But green transnational corporations, no matter what their country of origin, have no commitment to transform labor relations, nor can they within the straitjacket of the market. Alternative energy transnationals may be concerned over the fate of our planet, but much less so about the lives of the green proletariat. So too in China, where the working class has undergone the commodification of its labor, bought or discarded by the determined needs of their corporate employers, whether state-owned or 
private. If green jobs are to be good jobs it will depend on the strength and organization of workers themselves to change social relations.

Short of moving global capitalism towards market socialism, is the formation of a clearly define green strategy for a contending sector of the TCC. China's efforts are part of an endeavor to create a new round of worldwide accumulation based in green technologies. This sector of the TCC spans borders and may offer capitalism its only viable alternative to further finalization, speculation, and collapse. It's configuration also spans old political divisions. For example, in the U.S. it includes Robert Rubin, former secretary of the Treasury under Bill Clinton and top CITI executive, Henry Paulson, former secretary of Treasury under George W. Bush and CEO of Goldman Sachs, and Michael Bloomberg, Wall Street billionaire and former independent Mayor of New York. For these members of the ruling class, the efforts of the CCP look more appealing than Trump's promotion of coal.

Lastly, considering Chinese socialism, it must go far beyond economic development. If that is the main category of judgment then Taiwan, South Korea, and Singapore are all socialist countries. The CCP would argue for the long view. That the means of production need to be fully modernized and developed before the transformation in labor relations can take place. That socialism will never be built upon poverty. Indeed, that was a major point of debate and conflict in the Cultural Revolution - the Maoist wing of the $\mathrm{CCP}$ contending that a revolution in social relations was necessary to create the subjective force and enthusiasm to transform the means of production. That ideological and strategic approach was roundly defeated. Now, for the foreseeable future, the economic base will be the focus of attention, as China strives to develop a "moderately wealthy" society. Xi Jinping termed China's present developmental phase as "socialist modernization," but stated only by 2050 will China become a fully "modern socialist country" (Diaz et al., 2018). Future history will reveal if it has taken the capitalist or socialist road to achieve its developmental ends.

\section{References}

AITKEN, Roger. Bank of China's \$500 M LSE 'Green' Bond listing cements exchange's position, 2016. Forbes, Nov 11, 2016. Available from: www.forbes. $\mathrm{com} /$ sites/rogeraitken/2016/11/11/bank-of-chinas-500m-london-green-bond-listingcements-exchanges-position/\#29360ea49473. (11 Nov. 2016).

BNEF: Bloomberg New energy finance. 2q 2017 Frontier power market outlook. BNEF, 2017a. Available from: https://about.bnef.com/blog/2q-2017-frontier-powermarket-outlook/. (2 May 2017). 
BNEF: Bloomberg New energy finance. Runaway 53GW Solar boom in china pushed global clean energy investment ahead in 2017, 2017b. Available from: https://about. bnef.com/blog/runaway-53gw-solar-boom-in-china-pushed-global-clean-energyinvestment-ahead-in-2017/. (16 Jan. 2018).

BO, Kong; GALLAGHER, Kevin P. The globalization of Chinese energy companies: the role of state finance. Boston University: Global Economic Governance Initiative, 2016.

BRADSHER, Keith. When solar panels became job killers. The New York Times, 2017a. Available from: www.nytimes.com/2017/04/08/business/china-trade-solarpanels.html. (8 Apr. 2017).

BRADSHER, Keith. China looks to capitalize on clean energy as U.S. retreats. The New York Times, 2017b. Available from: www.nytimes.com/2017/06/05/business/ energy-environment/china-clean-energy-coal-pollution.html. (5 June 2017).

BRADSHER, Keith. Trump's first major trade fight with China could be over solar panels. The New York Times, 2017c. Available from: www.nytimes.com/2017/12/01/ business/trump-china-trade-solar.html. (1 Dec. 2017).

BRADSHER, Keith. At Davos, the real star may have been China, not Trump. The New York Times, 2018. Available from: www.nytimes.com/2018/01/28/business/ davos-trump-china.html. (28 Jan. 2018).

BUCKLEY, Tim; NICHOLAS, Simon. China's global renewable energy expansion. Institute for Energy Economics and Financial Analysis, 2017. Available from: http://ieefa.org/wp-content/uploads/2017/01/Chinas-Global-RenewableEnergy-Expansion_January-2017.pdf. (28 Jan. 2017). https://doi.org/10.18411/ a-2017-023

CLARK, Pilita. China retakes renewables investment lead. Financial Times, 2013. Available from: www.ft.com/content/ccfb504a-5e32-11e2-8780-00144feab49a. (14 Jan. 2013).

CLIMATESCOPE. Efforts to address climate through clean energy lag in emerging markets. Bloomberg New Energy Finance, 2017. Available from: http://globalclimatescope.org/en/blog/2017/11/06/PR/. (6 Nov. 2017).

DIAZ, Jose A.; ROMERO, Tania. China seeks to become a "socialist country" by 2050. Equal Times, 2018. Available from: www.equaltimes.org/china-seeks-tobecome-a-socialist?lang=en\#.WoCOYSXwaM8. (30 Jan. 2018).

FORSYTHE, Michael. China curbs plans for more coal-fired power plants. The New York Times, 2016. Available from: https://www.nytimes.com/2016/04/26/business/ energy-environment/china-coal.html. (25 Apr. 2016).

FRANKEL, David; PERRINE, Aaron; PINNER, Dickon. How-solar-energy-canfinally-create-value. McKinsey \& Company, 2016. Available from: www.mckinsey. $\mathrm{com} /$ business-functions/sustainability-and-resource-productivity/our-insights/howsolar-energy-can-finally-create-value. (15 Oct. 2016). 
GALLAGHER, Kevin P., KAMAL, Rohini; WANG, Yongzhong. Fueling growth and financing risk: the benefits and risks of China's development finance in the global energy sector. Boston University: Global Economic Governance Initiative Working Paper 002, 2016. Available from: www.bu.edu/pardeeschool/files/2016/05/FuelingGrowth.FINAL_.version.pdf. (May 2016).

GEGI: Global Economic Governance Initiative. China's global energy finance. Boston University: Global Economic Governance Initiative, 2016. Available from: www. bu.edu/cgef/\#/a11/EnergySource. (2016).

GSIA: Global Sustainable Investment Alliance. Global Sustainable Investment Review, 2016. Available from: www.gsi-alliance.org. (2016).

GUPTA, Anand. A Billion-dollar Green Bond wets French railway operator's appetite. Bloomberg New Energy Finance, 2017. Available from: www.eqmagpro. com/a-billion-dollar-green-bond-whets-french-railway-operators-appetite/. (29 March 2017).

IRENA: International Renewable Energy Agency. Renewable energy and jobs: annual review, 2017. Abu Dhabi: International Renewable Energy Agency, 2017. https://doi. org/10.1787/9789264178007-en

JIAJUN, Xu; GALLAGHER, Kevin P. Learning from the South: development finance institutions and green structural transformation. Boston University: Global Development Policy Center Policy Brief 003, 2017.

JINKOSOLAR. About JinkoSolar Holding Co., LTD., 2018. Available from: www.jinkosolar.com/about_1.html?lan=en. (2018).

KOOP, Fermin. China's impressive stake in Latin America's renewables. China Dialogue, 2016. Available from: www.chinadialogue.net/article/show/single/en/9419China-s-impressive-stake-in-Latin-America-s-renewables. (22 Nov. 2016).

LIEBREICH. Michael. Liebreich: A year of hectic change and off-target predictions. Bloomberg New Energy Finance, 2016. Available from: https://about.bnef.com/blog/ liebreich-year-hectic-change-off-target-predictions/. (14 Dec. 2016).

LIEBREICH, Michael; McCRONE, Angus. Shift to base-cost renewables: 10 predictions for 2017. Bloomberg New Energy Finance, 2017. Available from: https:// about.bnef.com/blog/10-renewable-energy-predictions-2017/. (18 Jan. 2017).

MIDDLEHURST, Charlotte. China emerges as global leader in clean energy. China Dialogue, 2017. www.chinadialogue.net/blog/9534-China-emerges-as-global-leaderin-clean-energy/en. (6 Jan. 2017). https://doi.org/10.1063/pt.5.025179

NG, Eric. China's clean-energy giants on an overseas shopping spree. South China Morning Post, 2016. Available from: www.scmp.com/business/companies/ article/2053910/chinas-clean-energy-giants-overseas-shopping-spree. (12 Dec. 2016).

REN Peng; CHANGE, Liu; LIWEN, Zhang. China's involvement in coal-fired power projects along the Belt and Road. Global Environmental Institute, 2017. 
RUETER, Gero; KUEBLER, Martin. China leading the way in solar energy expansion as renewables surge. $D W N e w s, 2017$. Available from: www.dw.com/en/china-leadingthe-way-in-solar-energy-expansion-as-renewables-surge/a-39081117. (7 June 2017).

TABUCHI, Hiroko. As Beijing joins climate fight, Chinese companies build coal plants. The New York Times, 2017. Available from: www.nytimes.com/2017/07/01/ climate/china-energy-companies-coal-plants-climate-change.html. (1 July 2017).

TIANJIE, Ma. President Xi champions low-carbon development at Davos. China Dialogue, 2017. Available from: www.chinadialogue.net/article/show/single/en/ 9553-President-Xi-champions-low-carbon-development-at-Davos. (16 Jan. 2017).

TRINASOLAR. Management Team, 2018. Available from: www.trinasolar.com/us/ our-company/management-team. (Jan. 2018).

WONG, Edward. Glut of coal-fired plants raises doubts about China's energy priorities. The New York Times, 2015. Available from: www.nytimes.com/2015/11/12/ world/asia/china-coal-power-energy-policy.html. (11 Nov. 2105).

XINHUA. China central bank official urges efforts to boost green financing. China Daily, 2017. Available from: www.chinadaily.com.cn/business/2017-04/15/content_ 28942652.htm. (15 Apr. 2017).

XU, Jiajun; GALLANGER, Kevin P. Leading from the South: development finance institutions and green structural transformation. Boston University: Global Development Policy Center Policy Brief 003, 2017.

Received at: 29 Sept. 2018

Approved at: 15 Jan. 2019

Published at: 30 July 2019

Corresponding author:

Jerry Harris

National Secretary - Global Studies Association of North America

1250 North Wood Street

Chicago, Illinois, 60622, USA

JERRY HARRIS < gharris234@comcast.net>

National Secretary of the Global Studies Association of North America (Chicago, USA).

Orcid: https://orcid.org/0000-0003-4658-0314 